HABITAT, 30 (2), 2019, 62-70

DOI: 10.21776/ub.habitat.2019.030.2.8

\title{
Analisis Faktor-Faktor yang Mempengaruhi Tingkat Partisipasi Petani Dalam Program Asuransi Usahatani Padi (AUTP) di Desa Watugede, Kecamatan Singosari, Kabupaten Malang
}

\section{Analysis of Factors Affecting Level of Farmers Participation in Insurance For Paddy Farming (AUTP) Program in Watugede Village, Singosari Subdistrict of Malang Regency}

\author{
Thalia Malirisa Marphy $^{1 *}$, Dina Novia Priminingtyas ${ }^{2}$ \\ Jurusan Sosial Ekonomi, Fakultas Pertanian,Universitas Brawijaya, J1. Veteran 65145, Malang, Jawa \\ Timur, Indonesia
}

Received: 26 November 2018; Revised: 5 April 2019; Accepted: 14 June 2019

\begin{abstract}
ABSTRAK
Penelitian ini bertujuan untuk menganalisis tingkat partisipasi petani pada program (Asuransi Usahatani Padi) AUTP dan menganalisis pengaruh faktor usia, pendidikan, pengalaman usahatani, luas lahan dan pendapatan terhadap partisipasi petani dalam program AUTP. Penelitian ini dilakukan kepada petani yang tergabung pada Gapoktan Makmur Sentosa yang mengikuti program AUTP dengan metode penentuan responden simple random sampling. Penelitian ini menggunakan pendekatan kuantitatif. Untuk menganalisis tingkat partisipasi petani dalam program AUTP dihitung menggunakan skala likert (Likert Summated Rating) dan untuk menganalisis faktor-faktor yang mempengaruhi partisipasi petani dalam program AUTP menggunakan metode analisis linier berganda. Hasil dari penelitian menunjukkan bahwa faktor usia, pendidikan, pengalaman usahatani, luas lahan dan pendapatan secara bersama-sama memiliki pengaruh terhadap tingkat partisipasi petani dalam program AUTP. Secara parsial usia, pendidikan dan pengalaman usahatani memiliki pengaruh positif dan signifikan sedangkan faktor luas lahan dan pendapatan tidak berpengaruh signifikan terhadap tingkat partisipasi petani dalam program AUTP di Desa Watugede.
\end{abstract}

Kata kunci: asuransi pertanian, program AUTP, partisipasi, analisis regresi berganda

\section{ABSTRACT}

The aims of this research are to analyze level of farmers participation level in AUTP program and to analyze affect of age, education, farming experience, land area and income in farmer participation in AUTP Program. This research was conducted to the farmers who joined Gapoktan Makmur Sentosa and joined AUTP program with method of determining respondents is simple random sampling. This research used a quantitative approach. To analyze farmer participation level in AUTP program was calculated using Likert Summated Rating scale and to analyze the factors that affect farmer participation in AUTP program using multiple linear analysis method.The results of this research indicate that the factors of age, education, farming experience, land area and income together affected level of farmers participation in the AUTP program. Partially age, education and farming experience have positive and significant affect while land and income factor were not significant affected level of farmers participation in AUTP program in Watugede Village.

Keyword: agriculture insurance, AUTP program, participation, multiple linier analysis

\section{How to Cite:}

Marphy, T. M., Priminingtyas, D. N., Ekonomi, J. S., Pertanian, F., Brawijaya, U., \& Veteran, J. (2019). Analisis Faktor-Faktor yang Mempengaruhi Tingkat Partisipasi Petani Dalam Program Asuransi Usahatani Padi ( AUTP ) di Desa Watugede, Kecamatan Singosari , Kabupaten Malang. HABITAT, 30(2), 62-70. https://doi.org/10.21776/ub.habitat.2019.030.2.8 


\section{Pendahuluan}

Indonesia merupakan negara kepulauan terbesar di dunia dan berada di jalur cicin api pasifik yang menyebabkan Indonesia rawan terhadap bencana alam. Posisi geografis tersebut menyebabkan Indonesia rentan akan dampak negatif dari perubahan iklim yang sudah mulai dirasakan seperti musim kemarau berkepanjangan, banjir dan cuaca yang ekstrim. Hal ini akan mengakibatkan dampak buruk bagi kesehatan dan kesejahteraan penduduk serta mengancam keanekaragaman hayati dan stabilitas ekonomi indonesia. Hal tersebut berkaitan dengan sektor pertanian yang merupakan salah satu sektor penting dalam perekonomian Indonesia.

Peran sektor pertanian adalah sebagai penyedia sumber pangan bagi masyarakat, sumber pendapatan nasional, membuka kesempatan kerja, sumber investasi serta penghasil devisa negara ketika produk-produk hasil pertanian diekspor ke negara lain. Disisi lain, sektor pertanian juga merupakan salah satu sektor yang paling rawan terhadap dampak negatif perubahan iklim. Perubahan iklim dan hama penyakit membuat fluktuasi produksi padi pada sektor pertanian di Indonesia terjadi. Penurunan produksi hasil bahkan gagal panen serta risiko fluktuasi harga dapat menyebabkan pendapatan petani menurun. Petani akan menderita kerugian yang cukup besar sehingga untuk usaha berikutnya tidak memiliki modal lagi. Maka dari itu, peran usahatani tanaman padi dalam memenuhi kebutuhan pangan tampaknya harus disertai dengan persiapan sifat pertanian yang rawan risiko.

Asuransi pertanian merupakan salah satu alternatif instrumen manajemen risiko yang layak dipertimbangkan, khususnya untuk menanggulangi kerugian. Asuransi pertanian berhubungan dengan pembiayaan usahatani dengan pihak ketiga (lembaga atau perusahaan, swasta atau instansi pemerintah) dengan jumlah tertentu dari pembiayaan premi (World Bank, 2008). Asuransi pertanian untuk komoditas padi di Indonesia dikenal dengan program Asuransi Usahatani Padi (AUTP). Undang-Undang Nomor 19 Tahun 2013 tentang Perlindungan dan Pemberdayaan Petani menyebutkan bahwa asuransi pertanian merupakan salah satu alat bagi

\footnotetext{
${ }^{*}$ Penulis Korespondensi.

E-mail:thaliamalirisa@gmail.com
}

pemerintah untuk melindungi petani dari gagal panen. Pasal 39 ayat (1) dan (2) UU 19/2013 menyatakan bahwa sesuai dengan kewenangannya, pemerintah pusat dan pemerintah daerah memfasilitasi setiap petani menjadi peserta asuransi. Salah satu fasilitas tersebut adalah bantuan pembayaran premi.

Desa Watugede juga merupakan satusatunya desa di kecamatan Singosari yang telah berpartisipasi menjadi peserta AUTP. Proses untuk membuat petani di Gapoktan Makmur Sentosa Desa Watugede untuk ikut berpartisipasi dalam program AUTP tidak mudah. Walaupun hama seperti tikus, penggerek batang padi dan wereng serta penyakit kresek sering menyerang sawah para petani tetapi masih banyak petani yang tidak percaya dengan lembaga asuransi. Sulitnya proses klaim dan lamanya petugas asuransi untuk datang mensurvey lahan yang terkena gagal panen membuat petani tidak percaya kepada lembaga asuransi. Hal ini mungkin disebabkan karena kurangnya informasi mengenai asuransi pertanian. Kepercayaan petani terhadap lahan padi yang belum tentu mengalami gagal panen juga menjadi alasan program AUTP sulit diterima para petani. Petani akhirnya menjadi enggan untuk membayar premi. Alasanalasan tersebut menjadi penghambat petani di Desa Watugede untuk berpartisipasi dalam program AUTP. Walaupun petani tidak percaya terhadap lembaga asuransi, petani Gapoktan Makmur Sentosa tetap berpartisipasi menjadi peserta AUTPkarena sektor pertanian merupakan sektor yang rentan akan risiko gagal panen. Maka dari itu, penelitian mengenai faktor-faktor apa saja yang mempengaruhi tingkat partisipasi petani dalam program Asuransi Usahatani Padi (AUTP) di Desa Watugede, Kecamatan Singosari, Kabupaten Malang perlu dilakukan.

\section{Metode Penelitian}

Penelitian ini menggunakan pendekatan kuantitatif yang dilakukan di Desa Watugede, Kecamatan Singosari, Kabupaten Malang. Pemilihan lokasi ini dikarenakan Desa Watugede merupakan salah satu desa di Kabupaten Malang yang sebagian besar petaninya telah berpartisipasi dan sudah lebih dari 4 kali menjadi peserta program AUTP. Penelitian ini dilakukan pada bulan Februari sampai dengan bulan Maret 2018.

Metode pengambilan sampel menggunakan simple random sampling. Sampel dalam penelitian ini adalah petani yang tergabung dalam Gapoktan Makmur Sentosa yang telah 
menjadi peserta program AUTP. Metode pengambilan sampel pada penelitian ini menggunakan rumus slovin yang dapat dilihat sebagai berikut:

$$
\mathrm{n}=\frac{N}{1+N e^{2}}
$$

Keterangan:

$$
\begin{array}{ll}
\mathrm{n} & \text { : Jumlah sampel } \\
\mathrm{N} & \text { : Jumlah populasi } \\
\mathrm{e} & \text { : Batas toleransi kesalahan }(15 \%)
\end{array}
$$

Berdasarkan data pada Gapoktan Makmur Sentosa dan menurut rumus yang digunakan pada penentuan sampel dapat diambil sampel sebanyak 36 orang tetapi sampel yang digunakan dalam penelitian ini sebanyak 40 orang.

Penelitian ini menggunakan dua jenis pengumpulan data, yaitu data primer seperti kuisioner, observasi dan dokumentasi dan data sekunder seperti pustaka dan data dari lembaga yang terkait dengan penelitian ini.Metode untuk menganalisis tingkat partisipasi petani dalam program AUTP yaitu menggunakan skala likert (Likert Summated Rating). dengan lima alternatif jawaban yaitu sangat sering, sering, sedang, tidak sering dan tidak pernah. Setiap alternatif jawaban memiliki skor. Jumlah skor pada masing-masing variabel dibagi menjadi tiga kategori yaitu tinggi, sedang dan rendah. Pembagian tiga kategori nilai dihitung dengan cara sebagai berikut:

Skor minimal $=$ Skor terkecil $\mathrm{x}$ jumlah item $\mathrm{x}$ jumlah responden

Batas $1=$ Skor minimal $+[$ (skor maksimal - skor minimal) x $1 / 3$ ]

Batas $2=$ Skor minimal $+[$ (skor maksimal - skor minimal) x 2/3]

Skor maksimal $=$ Skor terbesar $\mathrm{x}$ jumlah item $\mathrm{x}$ jumlah responden

Menentukan definisi batasan setiap nilai ditentukan dengan melihat posisi skor total variabel dalam interval nilai yang telah dibuat yaitu:

Skor minimal sampai batas 1 yaitu rendah

Batas 1 sampai batas 2 yaitu sedang

Batas 2 sampai skor maksimal yaitu tinggi

Metode analisis yang digunakan untuk menganalisis faktor-faktor yang mempengaruhi tingkat partisipasi petani dalam program AUTP yaitu analisis regresi linier berganda menggunakan SPSS 21. Agar model regresi yang digunakan mempunyai tingkat keakuratan dan validitas yang baik, sebelum dilakukan analisis regresi berganda dilakukan uji asumsi klasik. Dalam penelitian ini uji asumsi klasik yang dipakai adalah uji normalitas, uji multikolinearitas, dan uji heteroskedastisitas. Persamaan regresi yang dipakai adalah sebagai berikut (Supranto, 1999):

$\mathrm{Y}=\beta 1 \mathrm{X} 1+\beta 2 \mathrm{X} 2+\beta 3 \mathrm{X} 3+\beta 4 \mathrm{X} 4+\beta 5 \mathrm{X} 5+\mathrm{e}$

Keterangan :

$\mathrm{Y}=$ Tingkat partisipasi

$\beta 1=$ Koefisien regresi dari variabel X1 (usia)

$\mathrm{X} 1=\mathrm{Usia}$ (tahun)

$\beta 2=$ Koefisien regresi dari variabel X2

(Pendidikan)

X2 =Pendidikan (tahun)

$\beta 3=$ Koefisien regresi dari variabel $\mathrm{X} 3$

(Pengalaman usahatani)

X3 = Pengalaman usahatani (tahun)

$\beta 4=$ Koefisien regresi dari variabel $X_{4}$ (Luas lahan)

X4 = Luas lahan (hektar)

$\beta 5=$ Koefisien regresi dari variabel $\mathrm{X} 5$ (Pendapatan)

X5 = Pendapatan (rupiah)

$\mathrm{e}=$ Standar error

Pengujian model regresi dapat diukur dari goodness of fit. Pengujian goodness of fit model regresi dilakukan dengan uji $\mathrm{F}$, koefisien determinasi $\left(\mathrm{R}^{2}\right)$ dan uji signifikasi parameter masing-masing variabel dengan uji t.

\section{Hasil dan Pembahasan}

\subsection{Gambaran Umum Daerah Penelitian}

Desa Watugede termasuk dalam wilayah Kecamatan Singosari, Kabupaten Malang, Provinsi Jawa Timur. Secara Geografis Desa Watugede terletak pada koordinat $7,5317^{\circ} \mathrm{LS}$ dan $112,4235^{\circ} \mathrm{BT}$ dengan suhu rata-rata $17-27^{\circ} \mathrm{C}$. adapun topografi ketinggian Desa Watugede yaitu 487 mdpl dengan kemiringan tanah 3-5\% sehingga merupakan dataran tinggi. Jarak antara Desa Watugede dengan pusat pemerintahan Kecamatan Singosari $\pm 1,5 \mathrm{~km}$ atau terletak di sebelah utara pusat pemerintahan Kabupaten Malang. Wilayah Desa Watugede dengan seluas 315,334 ha merupakan salah satu desa yang memiliki luas wilayah yang cukup besar di Kecamatan Singosari Kebupaten Malang. Terletak diketinggian antara 4880 sampai dengan $540 \mathrm{~m}$ diatas permukaan laut dengan kemiringan tanah 3\% sampai $5 \%$ sehingga dapat topografi Desa Watugede merupakan dataran tinggi. Keadaan iklim di Desa Watugede adalah tropis dengan dua musim yaitu musim penghujan dan kemarau. Curah hujan pada lima tahun terakhir sejumlah rata-rata $14,72 \mathrm{ml}$ hujan per hari dengan tujuh bulan basah dan lima bulan kering. Dengan 
demikian keadaan tanah dan iklim di daerah penelitian dapat dikatakan cocok digunakan sebagai lahan pertanian terutama untuk komoditas padi.

\subsection{Tingkat Partisipasi Petani Padi dalam Program AUTP}

Tingkat partisipasi petani dalam program AUTP secara keseluruhan memiliki total skor sebesar 582 yang berada pada interval skor 561 sampai dengan 800 sehingga tergolong kategori tinggi. Tingkat partisipasi petani padi di Desa Watugede dalam program AUTP dapat dilihat dari tahap dalam partisipasi menurut Menurut Cohen dan Uphoff yang dikutip oleh Astuti (2011). Hal tersebut dapat dilihat dari skor masing-masing variabel tingkat partisipasi yang terdiri dari mengikuti sosialisasi program AUTP (143), mendaftar program AUTP (178), berkonsultasi atau berdiskusi mengenai program AUTP (143), dan pemantauan program AUTP atau survei klaim

(118).

Tabel 1. Tingkat Partisipasi Petani dalam Program AUTP

\begin{tabular}{|c|c|c|c|c|}
\hline \multirow[b]{2}{*}{ Variabel/Indikator } & \multirow{2}{*}{$\begin{array}{l}\text { Total } \\
\text { Skor }\end{array}$} & \multicolumn{3}{|c|}{ Interval Skor } \\
\hline & & Tinggi & Sedang & Rendah \\
\hline Mengikuti sosialisasi program AUTP & 143 & $148-200$ & $94-147$ & $40-93$ \\
\hline Mendaftar AUTP & 178 & $148-200$ & $94-147$ & $40-93$ \\
\hline $\begin{array}{ll}\text { Berkonsultasi atau } & \text { berdiskusi } \\
\text { mengenai program AUTP } & \end{array}$ & 143 & $148-200$ & $94-147$ & $40-93$ \\
\hline $\begin{array}{l}\text { Mengikuti pemantauan program AUTP } \\
\text { atau survei klaim }\end{array}$ & 118 & $148-200$ & $94-147$ & $40-93$ \\
\hline
\end{tabular}

\begin{tabular}{ccc}
\hline Total Tingkat partisipasi petani & 582 \\
\hline Tingginya partisipasi & petani & dalam
\end{tabular}
program AUTP karena program AUTP sangat membantu para petani untung menghadapi kemungkinan risiko yang terjadi. Tingginya risiko yang ditanggung petani terutama yang disebabkan serangan hama di Desa Watugede membuat para petani sering merugi sehingga pendapatan ekonomi petani berkurang. Sudah lebih dari 4 kali musim tanam berturut-turut sebelum mengikuti program AUTP petani padi di Desa Watugede mengalami gagal panen. Program AUTP memberikan perlindungan terhadap petani dari ancaman risiko gagal panen tersebut. Setelah sudah tiga sampai empat kali mendaftar menjadi peserta program AUTP, sawah di Desa Watugede baru mengalami klaim hanya satu kali. Program AUTP memberikan modal untuk para petani agar dapat melakukan usahatani di musim tanam berikutnya. Program AUTP juga mendorong minat petani di Desa Watugede untuk meningkatkan keterampilan dan perbaikan manajemen usahatani serta meningkatkan pendapatan para petani dalam melaksanakan usahatani.

$561-800 \quad 301-560 \quad 80-300$

Partisipasi petani yang mengikuti program AUTP berdasarkan Pretty dan Adnan dalam Pretty dan Vodouhe (1997), termasuk dalam tipologi partisipasi dengan tipologi partisipasi dengan konsultasi. Pihak luar seperti lembaga asuransi dan pemerintah menetapkan masalah (gagal panen) dan menciptakan jalan keluarnya dengan mencetuskan program AUTP untuk memecahkan alasan tersebut. Pengambilan Keputusan lahan sawah tersebut dapat diklaim atau tidak dengan asuransi berada di pihak lembaga asuransi.

\subsection{Faktor-Faktor yang Mempengaruhi Partisipasi Petani dalam Program Asuransi Usahatani Padi (AUTP)}

Hasil penelitian yang telah memenuhi syarat uji asumsi klasik dapat dianalisis dengan regresi linier berganda. Analisis regresi linier bertujuan untuk mengetahui pengaruh variabel independen terhadap variabel dependen. Pengolahan data dengan menggunakan program SPSS pada penelitian ini menghasilkan koefisien regresi yang dpat dilihat tabel berikut ini:

Table 2. Hasil Analisis Regresi

\begin{tabular}{lccccc}
\hline \multirow{2}{*}{ Model } & \multicolumn{2}{l}{$\begin{array}{l}\text { Unstandardized } \\
\text { Coefficients }\end{array}$} & $\begin{array}{l}\text { Standardized } \\
\text { Coefficients }\end{array}$ & T & Sig. \\
\cline { 2 - 7 } & $\mathrm{B}$ & $\begin{array}{c}\text { Std } \\
\text { Error }\end{array}$ & Beta & & \\
\hline (Constant) & 7.005 & 2.816 & & & \\
Usia (X1) & -.102 & .050 & -.298 & -.2 .056 & $.048 *$
\end{tabular}




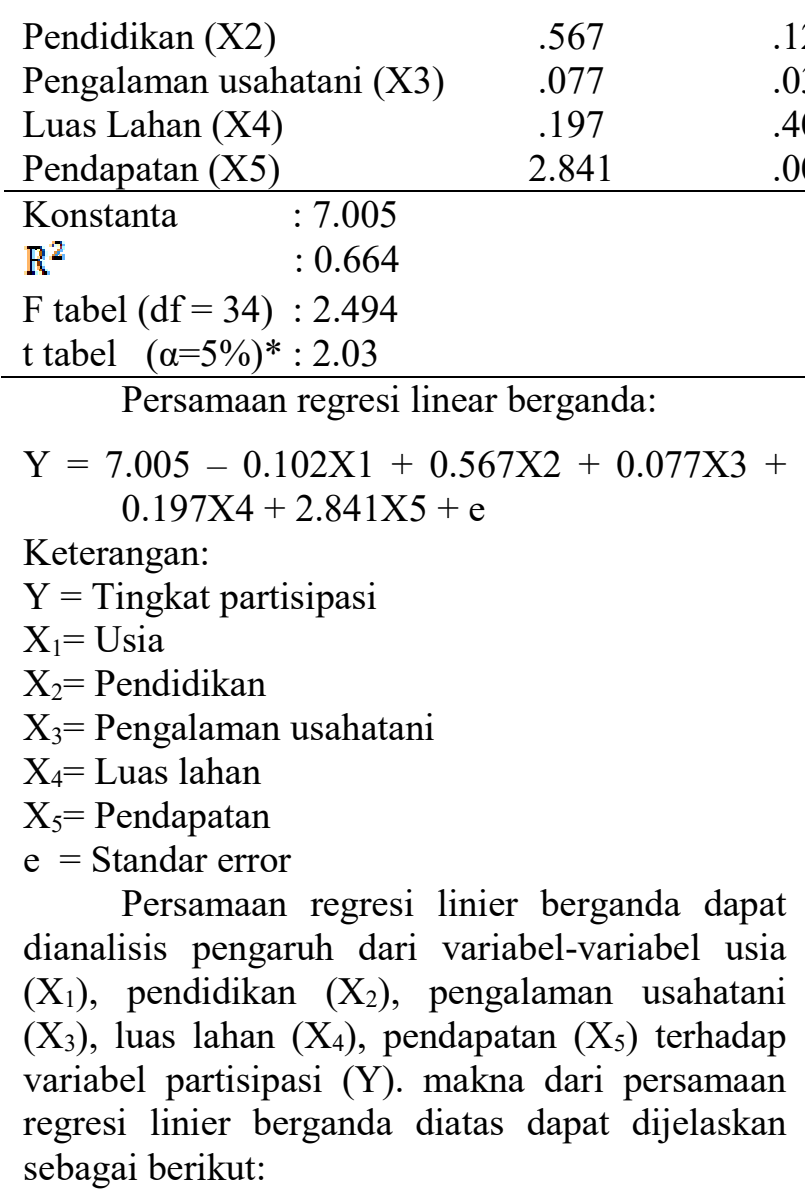

a. Usia $\left(\mathrm{X}_{1}\right)$

Koefisien regresi variabel usia $(\beta 1)$ bernilai negatif sebesar -0.102 , menunjukkan bahwa penambahan satu tahun pada usia petani, dapat mengurangi minat partisipasi petani padi dalam program AUTP di Desa Watugede.

b. Pendidikan $\left(\mathrm{X}_{2}\right)$

Koefisien regresi variabel pendidikan $(\beta 2)$ bernilai positif sebesar 0.567 , menunjukkan bahwa penambahan satu tahun lamanya petani menempuh pendidikan, dapat meningkatkan minat partisipasi petani padi dalam program AUTP di Desa Watugede.

\section{c. Pengalaman usahatani $\left(\mathrm{X}_{3}\right)$}

Koefisien regresi pengalaman usahatani ( $\beta 3$ ) bernilai positif sebesar 0.077 , menunjukkan bahwa penambahan satu tahun lamanya pengalaman usahatani petani, dapat meningkatkan minat partisipasi petani padi dalam program AUTP di Desa Watugede.

\section{d. Luas lahan $\left(\mathrm{X}_{4}\right)$}

Koefisien regresi luas lahan ( $\beta 4)$ bernilai positif sebesar 0.197, menunjukkan bahwa penambahan sebesar satu hektar pada luas lahan, dapat meningkatkan minat partisipasi petani padi dalam program AUTP di Desa Watugede.

\section{e. Pendapatan $\left(\mathrm{X}_{5}\right)$}

Koefisien regresi pendapatan ( $\beta 5$ ) bernilai positi sebesar 2.841, menunjukkan bahwa penambahan sebesar Rp. 1 pada pendapatan petani, dapat meningkatkan minat padi partisipasi petani dalam program AUTP di Desa Watugede.

Setelah dilakukan uji analisis regresi berganda, dilakukan beberapa uji sebagai berikut:

\section{1) Uji F-Statistik}

Uji $F$ digunakan untuk mengetahui pengaruh variabel independen usia $\left(\mathrm{X}_{1}\right)$, pendidikan $\left(\mathrm{X}_{2}\right)$, pengalaman usahatani $\left(\mathrm{X}_{3}\right)$, Luas Lahan $\left(\mathrm{X}_{4}\right)$ dan pendapatan $\left(\mathrm{X}_{5}\right)$ terhadap partisipasi dalam program AUTP (Y) secara simultan (bersama-sama). Berikut hasil analisis uji $F$ menggunakan SPS:

Tabel 3. Hasil Uji F

\begin{tabular}{lllllll}
\hline Model & Sum of Squares & df & Mean Square & F & F tabel & Sig. \\
\hline Regression & 321.030 & 5 & 64.206 & 13.436 & 2.494 & 0.000 \\
Residual & 162.470 & 34 & 4.779 & & & \\
\hline Total & 483.500 & 39 & & & & \\
\hline
\end{tabular}

Hipotesis uji $\mathrm{F}$ :

Ho $: \beta 1=\beta 2=\beta 3=\beta 4=\beta 5=0$ (usia, pendidikan, pengalaman usahatani, luas lahan dan pendapatan secara simultan tidak berpengaruh terhadap partisipasi petani padi dalam program AUTP di Desa Watugede).
$H a \quad: \quad \beta 1 \neq \beta 2 \neq \beta 3 \neq \beta 4 \neq \beta 5 \neq \beta 6 \quad \beta \quad \neq 0 \quad$ (usia, pendidikan, pengalaman usahatani, luas lahan dan pendapatan secara simultan berpengaruh terhadap partisipasi petani padi dalam program AUTP di Desa Watugede). 
Diperoleh nilai $\mathrm{F}$ hitung sebesar 13.436 dan $F$ tabel sebesar 2.494 dengan signifikansi sebesar 0.000. oleh karena F hitung (13.436) > dari $\mathrm{F}$ tabel (2.494), dengan nilai signifikansi lebih kecil dari $0.05(0.000<0.05)$ maka Ho ditolak yang berarti usia, pendidikan, pengalaman usahatani, luas lahan dan pendapatan secara simultan berpengaruh terhadap partisipasi petani padi dalam program AUTP di Desa Watugede.
Koefisien determinasi $\left(\mathrm{R}^{2}\right)$ dilakukan untuk melihat adanya hubungan yang sempurna atau tidak yang ditunjukkan pada apakah perubahan variabel independen (usia, pendidikan, pengalaman usahatani, luas lahan dan pendapatan) akan diikuti oleh variabel dependen (partisipasi petani) pada proporsi yang sama. Hasil perhitungan $R$ square menggunakan SPSS 21 ditunjukkan pada tabel berikut:

2) Koefisien Determinasi $\left(R^{2}\right)$

Tabel 4. Hasil Pengujian R-Square

\begin{tabular}{|c|c|c|c|c|}
\hline Model & $\mathrm{R}$ & R Square & Adjusted R Square & Std. Error of the estimate \\
\hline 1 & $.815^{\mathrm{a}}$ & .664 & .615 & 2.186 \\
\hline
\end{tabular}

$\left(\mathrm{X}_{2}\right)$, pengalaman usahatani $\left(\mathrm{X}_{3}\right)$, luas lahan $\left(\mathrm{X}_{4}\right)$ dan pendapatan $\left(\mathrm{X}_{5}\right)$ terhadap variabel partisipasi (Y) yang diukur menggunakan R-Square sebesar 0.664 . Hal ini berarti bahwa variabel-variabel independen dalam model mampu menjelaskan variabel dependen sebesar $66.4 \%$. Sisanya $33.6 \%$ $(100 \%-66.4 \%)$ dijelaskan oleh variabel-variabel lain yang tidak dijelaskan dalam penelitian ini.

3) Uji t-Statistik

Uji $t$ dalam regresi linier berganda bertujuan untuk menguji apakah parameter (koefisien regresi dan konstanta) yang diduga untuk mengestimasi model regresi linier berganda sudah merupakan parameter yang tepat atau belum. Model harus mampu menjelaskan perilaku variabel independen usia $\left(\mathrm{X}_{1}\right)$, pendidikan $\left(\mathrm{X}_{2}\right)$, pengalaman usahatani $\left(\mathrm{X}_{3}\right)$, luas lahan $\left(\mathrm{X}_{4}\right)$ dan pendapatan $\left(\mathrm{X}_{5}\right)$ dalam mempengaruhi variabel dependen partisipasi petani dalam program AUTP di Desa Watugede (Y). Berikut merupakan hasil analisis faktorfaktor yang mempengaruhi tingkat partisipasi petani dalam program AUTP di Desa Watugede:

Tabel 5. Hasil Uji t-Statistik

\begin{tabular}{lllll}
\hline No & Variabel Independen & t hitung & t tabel & Sig. \\
\hline 1 & Usia (X1) & -2.056 & & $.048^{*}$ \\
2 & Pendidikan (X2) & 4.385 & & $.000^{*}$ \\
3 & Pengalaman usahatani (X3) & 2.346 & 2.03224 & $.025^{*}$ \\
4 & Luas lahan (X4) & 0.486 & & .630 \\
5 & Pendapatan (X5) & 0.817 & & .420 \\
& Variabel signifikan berpengaruh* & & & \\
\hline
\end{tabular}

H0 : Tidak ada pengaruh signifikan antara masing-masing variabel independen $(\mathrm{X})$ terhadap variabel dependen $(\mathrm{Y})$

$\mathrm{Ha}$ : Ada pengaruh signifikan antara masingmasing variabel independen $(\mathrm{X})$ terhadap variabel dependen $(\mathrm{Y})$

a) Usia

Tabel 4 menunjukkan nilai t-hitung sebesar 2.056 dan t-tabel pada $\alpha=5 \%$ yaitu 2.032 sehingga t-hitung (2.056) $>$ t-tabel (2.032) dan nilai Sig. $0.048<\alpha=0.05$ artinya secara parsial faktor usia mempengaruhi secara signifikan terhadap partisipasi petani dalam mengikuti program AUTP. Nilai $t$ hitung negatif hanya menunjukkan bahwa faktor usia (X1) mempunyai hubungan berlawanan dengan tingkat partisipasi (Y).

Koefisien pada variabel usia (X1) bernilai negatif memiliki arti penambahan satu tahun pada usia petani, dapat mengurangi minat tingkat partisipasi petani padi dalam program AUTP di Desa Watugede. Menurut Girsang (2011), semakin tinggi usia maka akan semakin tinggi pula tingkat partisipasi seseorang. Namun bukan berarti tidak ada batasan pada penambahan partisipasi pada usia yang terus bertambah. Sebagian besar petani di Desa Watugede ada pada usia produktif maka tingkat partisipasi para petani pun tinggi dalam suatu program seperti hadir pada saat pertemuan gapoktan atau poktan (Kelompok Tani) dan aktif bertanya kepada pengurus Gapoktan Makmur Sentosa. Tetapi bagi para petani yang memiliki usia produktif yang akan memasuki usia tua ( $>55$ tahun) akan sedikit sulit untuk memahami suatu program baru. Hal 
ini sejalan dengan penelitian yang dilakukan oleh Tenriawaruwaty (2013), yang menyatakan seseorang telah berumur tua akan memiliki kemampuan fisik yang menurun dan mengalami kesulitan dalam mengadopsi sesuatu.

\section{b) Pendidikan}

Tabel 4 menunjukkan nilai t-hitung sebesar 4.385 dan t-tabel pada $\alpha=5 \%$ yaitu 2.032 sehingga t-hitung (4.385) $>$ t-tabel (2.032) dan nilai Sig. $0.000<\alpha=0.05$ artinya secara parsial faktor pendidikan memiliki pengaruh secara signifikan terhadap tingkat partisipasi petani dalam mengikuti program AUTP.

Para petani di Desa Watugede yang memiliki pendidikan lebih tinggi akan lebih mudah menerima informasi mengenai program AUTP sehingga akan mengambil keputusan yang tepat untuk mengikuti program AUTP. Pendidikan memiliki pengaruh terhadap partisipasi petani dalam program AUTP sesuai dengan penelitian Prayuningtias (2017), yang mengatakan bahwa pendidikan mendorong keinginan petani untuk berpartisipasi dalam AUTP dan seperti yang dikatakan Siswadi dan Syakir (2016), bahwa pendidikan sangat berpengaruh terhadap keputusan responden dalam menerima inovasi baru. Semakin tinggi pendidikan responden maka akan lebih luas pengetahuan responden dan dapat lebih mudah menerima inovasi baru.

\section{c) Pengalaman Usahatani}

Tabel 4 menunjukkan nilai t-hitung sebesar

2.346 dan t-tabel pada $\alpha=5 \%$ yaitu 2.032 sehingga t-hitung $(2.346)>$ t-tabel $(2.032)$ dan nilai Sig. $0.025<\alpha=0.05$ artinya secara parsial faktor pengalan usahatani mempengaruhi secara signifikan terhadap tingkat partisipasi petani dalam mengikuti program AUTP.

Seiring berjalannya waktu dengan pengalaman usahatani yang bertambah, setelah melihat bukti daerah lain yang terbantu untuk mengatasi kerugian akibat gagal panen karena mengikuti program AUTP dan setelah merasakan manfaat dari mengikuti program AUTP, para petani di Desa Watugede menjadikan asuransi pertanian sebagai pilihan para petani sebagai wadah pengalihan risiko gagal panen. Semakin lama pengalaman usahatani petani di Desa Watugede akan semakin banyak juga pengalaman atau strategi para petani untuk mengatasi gagal panen. Hasil penelitian ini sesuai dengan penelitian yang dilakukan Kurniawan (2016), bahwa pengalaman berusahatani berpengaruh signifikan terhadap keberlanjutan usahatani dan seperti yang dinyatakan oleh Mulyati, Rochdiani dan Yusuf (2014), bahwa dengan pengalaman pada usahatani padi sawah yang lama, petani akan lebih terampil dalam mengatasi hambatan maupun tantangan yang mungkin terjadi pada usahatani berlangsung.

d) Luas Lahan

Tabel 4 menunjukkan nilai t-hitung sebesar 0.486 dan t-tabel pada $\alpha=5 \%$ yaitu 2.032 sehingga t-hitung $(0.486)<\mathrm{t}$-tabel $(2.032)$ dan nilai Sig $0.630>\alpha=0.05$ artinya secara parsial faktor luas lahan tidak memiliki pengaruh secara signifikan terhadap tingkat partisipasi petani dalam program AUTP.

Hasil tersebut sama seperti hasil penelitian Wahyudi (2015), mengenai skim ujicoba AUTP dan faktor-faktor yang berhubungan dengan partisipasi petani dalam AUTP yang menyatakan luas lahan tidak berpengaruh signifikan terhadap partisipasi petani. Berdasarkan hasil penelitian, para petani padi dengan luas lahan sempit dan luas lahan besar di Desa Watugede pun juga memiliki kesempatan yang sama dalam mengikuti program AUTP. Luas lahan tidak memiliki pengaruh terhadap tingkat partisipasi petani dalam program AUTP sesuai dengan penelitian yang dilakukan oleh Siswadi dan Syakir (2016), bahwa luas lahan tidak berpengaruh nyata terhadap respon petani dalam keikutsertaan asuransi usahatani padi karena petani yang mempunyai luas lahan sempit maupun luas lahan mempunyai kesempatan yang sama dalam keikutsertaan program asurani usahatani padi.

e) Pendapatan

Tabel 4 menunjukkan nilai t-hitung sebesar 0.817 dan t-tabel pada $\alpha=5 \%$ yaitu 2.032 sehingga t-hitung $(0.817)<$ t-tabel (2.032) dan nilai Sig. $0.420>\alpha=0.05$ artinya secara parsial faktor pendapatan tidak memiliki pengaruh secara signifikan terhadap tingkat partisipasi petani dalam mengikuti program AUTP.

Sebagian petani lain di Desa Watugede menganggap besar atau kecilnya pendapatan mereka tidak mempengaruhi tingkat partisipasi mereka dalam program AUTP karena mereka akan mendaftarkan lahan mereka untuk diasuransikan untuk menghindari risiko gagal panen yang mungkin terjadi. Hasil penelitian tersebut sama seperti hasil penelitian yang dilakukan oleh Falola, Ayinde dan Agboola (2013), bahwa beberapa petani dengan pendapatan yang tinggi menerapkan metode pengelolaan risiko yang lain meskipun dengan biaya tinggi. 
Bertani bukanlah mata pencaharian utama sebagian besar penduduk Desa Watugede. Berdasarkan karakteristik penduduk yang telah di jabarkan, sebagian besar penduduk Desa Watugede bekerja diluar sektor pertanian dan bertani merupakan pekerjaan sampingan para penduduk di Desa Watugede.

\section{Kesimpulan}

Peneliti ini menganalisis mengenai faktorfaktor yang mempengaruhi tingkat partisipasi petani petani dalam program Asuransi Usahatani Padi (AUTP) di Desa Watugede, Kecamatan Singosari, Kabupaten Malang. Kesimpulan yang dapat diperoleh dari hasil penelitian dan pembahasan yakni:

a. Tingkat partisipasi petani dalam program AUTP di Desa Watugede menurut perhitungan skala likert (Likert Summated Rating) termasuk dalam kategori tinggi dengan memiliki total skor sebesar 582.

b. Usia, pendidikan, pengalaman usahatani, luas lahan dan pendapatan secara bersamaan memiliki pengaruh terhadap tingkat partisipasi petani pada program AUTP. Usia, pendidikan dan pengalaman usahatani memiliki dampak positif dan signifikan dalam tingkat partisipasi petani dalam program AUTP sedangkan luas lahan dan pendapatan memiliki pengaruh negatif dan tidak signifikan dalam tingkat partisipasi petani dalam program AUTP.

Berdasarkan hasil kesimpulan, maka terdapat beberapa saran yang dapat dikemukakan terhadap hasil penelitian sebagai berikut:

a. Petani diharapkan lebih aktif dalam kegiatan atau rapat Gapoktan seperti sosialisasi dan diskusi agar mengetahui, memahami dan mendapat informasi yang runtut dan benar terhadap programprogram yang akan dijalankan.

b. Faktor pendidikan yang telah berpengaruh pada tingkat partisipasi petani pada program AUTP dapat menambah pengetahuan petani dan mudah menerima inovasi baru mengenai asuransi pertanian. Sehingga selain pendidikan formal, pendidikan non formal seperti pelatihan mengenai budidaya padi atau sosialisasi mengenai teknologi juga penting dilakukan untuk menambah pengetahuan petani. Pada faktor luas lahan yang tidak berpengaruh pada tingkat partisipasi petani sebaiknya mendaftar AUTP untuk seluruh lahan sawah yang ia miliki agar apabila terjadi gagal panen sawah mereka mendapatkan ganti rugi. Para petani yang memiliki pendapatan dari usahatani sebaiknya tidak ragu untuk mengasuransikan lahan mereka agar apabila terjadi gagal panen petani tidak mendapatkan kerugian finansial terlalu besar.

c. Apabila sawah mereka mengalami gagal panen, lebih baik sawah tidak langsung dipanen lagi agar pada saat survei klaim para surveyor dari lembaga asuransi melihat bukti bahwa lahan tersebut gagal panen.

\section{Daftar Pustaka}

Astuti, Sugandi, Hamdan. 2011. Faktor-Faktor yang Mempengaruhi Adopsi Petani Terhadap Inovasi Teknologi Jeruk Gerga Lebong di Provinsi Bengkulu. Jurnal Iptek Tanaman Pangan. Bengkulu: Balai Pengkajian Teknologi Pertanian Bengkulu.

Falola A, Ayinde OE dan Agboola Bo. 2013. Willingness to Take Agricultural Insurance by Cocoa Farmers In Nigeria. International Journal of Food and Agricultural Economics. Vol 1. No. 1 pp. 97-107.

http://www.foodandagriculturejournal.com 197.pdf. Diakses pada 25 April 2018.

Girsang, Lisbet Juwita. 2011. Faktor yang Mempengaruhi Partisipasi Masyarakat dalam Perbaikan Prasarana Jalan. Bogor: Intitut Pertanian Bogor.

Mulyati, Rochdiani, Yusuf. 2014. Pengaruh Faktor Sosial Ekonomi Petani dan Partisipasi Petani Dalam Penerapan Teknologi Pola Tanam Padi (Oryza sativa L) Jajar Legowo 4:1. Bandung: Universitas Padjajaran.

Prayuningtias, M. 2017. Analisis Faktor-Faktor yang Mempengaruhi Partisipasi Petani Dalam Asuransi Usaha Tanam Padi di Kabupaten Karawang. Surakarta: Universitas Sebelas Maret.

Pretty, Jules N \& Simplice, D. Vodouhe. 1997. Using Rapid or Participatory Rural Appraisal dalam Improving Agricultural Extension: A reference manual. Diedit oleh Burton E. Swanson, Robert P. Bentz, dan Andrew J. Sofranko. FAO. Rome. Hal 69 84. 
Siswadi, Bambang dan Syakir, F. 2016. Respon Petani Terhadap Program Pemerintah Mengenai Asuransi Usahatani Padi (AUTP). Malang: Seminar Nasional Pembangunan Pertanian.

Supranto, J. 1999. Pengukuran Tingkat Kepuasan Pelanggan. Jakarta : PT Rineka.

Wahyudi, I. 2015. Skim Ujicoba Asuransi Usahatani Padi da $n$ Faktor-Faktor yang Berhubungan dengan Partisipasi Petani Dalam Program AUTP. Bogor: Institut Pertanian Bogor.

World Bank. 2008. Overview on Agricultural Insurance: World Bank Report "Government Support to Agricultural Insurance, Challenges, and Options for Developing Countries". http://wwwesd.worldbank.org. Diakses pada tanggal 20 Desember 2017. 